\title{
Co-trimoxazole and Azathioprine: A Safe Combination
}

\author{
C. L. HALL
}

British Medical fournal, 1974, 4, 15-16

Methods

\section{Summary}

Ninety-four patients receiving immunosuppressive therapy with azathioprine and prednisone after human cadaver kidney transplantation developed urinary tract infections and were treated with co-trimoxazole or another antibiotic in a controlled randomized prospective trial. The incidence of leucopenia in the group treated with co-trimoxazole $(10.6 \%)$ was not significantly different from that in the group treated with other antibiotics (23.6\%). Leucopenia when it occurred did so soon after transplantation at a time when the function of the renal transplant was poor in relation to the dosage of azathioprine given. In all cases the temporary withdrawal of azathioprine relieved the leucopenia despite continuation of the co-trimoxazole treatment. This study did not provide any evidence that co-trimoxazole plus azathioprine was a more potent cause of leucopenia than azathioprine alone.

\section{Introduction}

The combination of trimethoprim and sulphamethoxazole (co-trimoxazole) is a powerful antibacterial substance, bacteriocidal for most organisms causing urinary tract infections. Clinical trials have shown its superiority to ampicillin (Reeves et al., 1969; Brumfitt and Pursell, 1972) and sulphonamides (Reeves et al., 1969; Grüneberg and Kolbe, 1969) in the treatment of these infections. They are, however, several reports of neutropenia (McCarthy, 1969; Paulley, 1970) and thrombocytopenia (Evans and Tell, 1969) occurring in association with co-trimoxazole therapy. These conditions have been attributed to hypersensitivity to the sulphonamide component (Bateman, 1973).

Hulme and Reeves (1971) reported that four patients who were receiving prednisone and azathioprine after successful cadaveric kidney transplantation developed a profound and sustained leucopaenia in association with co-trimoxazole therapy when given within 60 days of transplantation, and they recommended that extreme caution should be used in giving co-trimoxazole soon after transplantation. Episodes of urinary tract infection are a frequent complication of kidney transplantation consequent upon the surgical manipulation of the urinary tract and the presence of an indwelling urethral catheter. In the Birmingham unit co-trimoxazole has been used very successfully in the treatment of these infections. A retrospective survey showed that of 27 patients who had received a cadaver kidney transplant and also a course of co-trimoxazole eight had developed a leucopenia. In all eight cases the temporary withdrawal of azathioprine had relieved the leucopenia and in three cases co-trimoxazole had been continued throughout the period of the leucopenia and the recovery from it. Thus it was decided that rather than restrict the use of co-trimoxazole a randomized controlled prospective trial would be carried out to determine whether this drug could be incriminated as a cause of leucopenia in patients receiving azathioprine and prednisone after cadaver kidney transplantation.

M.R.C. Renal Research Laboratory, Queen Elizabeth Hospital, Birmingham B15 2TH

Ninety-four patients who were receiving routine immunosuppressive therapy with prednisone and azathioprine after human cadaver kidney transplantation developed urinary tract infections and were admitted to the trial. The infection was diagnosed only when the urine contained more than 100,000 organisms $/ \mathrm{ml}$ and more than 10 pus cells per highpower field. Patients were admitted to the trial only when the causative organism was sensitive both to co-trimoxazole and another antibiotic. The patients were randomized by means of a table of random numbers between the cotrimoxazole group and the "other antibiotic" group. The other antibiotics were ampicillin, nitrofurantoin, gentamicin, cephaloridine, nalidixic acid, and sulphadimide. No attempt was made to randomize treatment between the different antibiotics in this second group, in which ampicillin was used as the drug of first choice if the infecting organism was sensitive to it. Otherwise the choice of antibiotic was made according to the sensitivity of the infecting organism and the known toxic hazards of the different antibiotics in relation to the level of renal function of the individual patients. The urinary tract infections were treated for 14 days, and irrespective of renal function a co-trimoxazole dosage of two Septrin tablets twice daily (trimethoprim $320 \mathrm{mg} /$ day, sulphamethoxazole $1,600 \mathrm{mg} /$ day) and standard dosages of other antibiotics -for example, ampicillin $250 \mathrm{mg}$ four times daily, nitrofurantoin $100 \mathrm{mg}$ twice daily-were used.

Haematological and biochemical investigations were performed daily on inpatients and at each subsequent outpatient visit. Leucopenia was diagnosed when the total peripheral W.B.C. count was less than $5,000 / \mathrm{mm}^{3}$, at which level the azathioprine was reduced or discontinued until the W.B.C. count increased to more than $5,000 \mathrm{~mm}^{3}$

\section{Results}

The two groups were comparable in all respects (table I). The incidence of leucopenia, its time of onset, and duration were similar in the two groups and the patients were entirely comparable with regard to their renal transplant function and the dosage of azathioprine and prednisone (table II). The patients who developed a leucopenia while receiving an antibiotic are compared with those who did not in table III. The patients who developed a leucopenia did so when they received the antibiotic, whether co-trimoxazole or another antibiotic, relatively early after transplantation and at a time when the function of the renal transplant was poor, yet their azathioprine dosage was similar to that of the non-leucopenic patients who had significantly better renal function. The significantly higher dosage of prednisone in the leucopenic group was a reflection of their poor transplant function.

\section{Discussion}

These results confirm the findings of Hulme and Reeves (1971) that the incidence of leucopenia in the antibiotictreated, immunosuppressed renal transplant recipient is greatest in the early weeks after transplantation. In the present series the inclusion of a control group of patients treated for urinary tract infections with antibiotics other than co-trimoxazole showed that there were no significant differences in the incidence, time of onset, and duration of 
TABLE I-Comparison of Patients treated with Co-trimoxazole and those treated with Other Antibiotics. Results expressed as Means \pm S.D.

\begin{tabular}{|c|c|c|c|c|c|c|}
\hline & $\begin{array}{l}\text { No. of } \\
\text { Patients }\end{array}$ & $\begin{array}{c}\text { Day after } \\
\text { Transplantation at } \\
\text { Start of Treatment }\end{array}$ & $\begin{array}{l}\text { Blood Urea } \\
(\mathrm{mg} / 100 \mathrm{ml})\end{array}$ & $\begin{array}{c}\text { Azathioprine } \\
\text { (mg/day) }\end{array}$ & $\begin{array}{c}\text { Prednisone } \\
\text { (mg/day) }\end{array}$ & $\begin{array}{l}\text { W.B.C. at Start of } \\
\text { Treatment } / \mathrm{mm}^{3}\end{array}$ \\
\hline $\begin{array}{l}\text { Co-trimoxazole } \\
\text { Other antibiotics }\end{array}$ & $\begin{array}{l}47 \\
47\end{array}$ & $\begin{array}{l}208 \cdot 9 \pm 239 \cdot 2 \\
203 \cdot 4 \pm 246 \cdot 4\end{array}$ & $\begin{array}{l}78 \cdot 2 \pm 58 \cdot 2 \\
93.0 \pm 69 \cdot 2\end{array}$ & $\begin{array}{l}90.5 \pm 33.0 \\
91.5 \pm 24.6\end{array}$ & $\begin{array}{l}37.0 \pm 36.3 \\
41.5 \pm 46.9\end{array}$ & $\begin{array}{l}8,446 \cdot 8 \pm 2,947 \cdot 4 \\
8,936 \cdot 1 \pm 3,726 \cdot 5\end{array}$ \\
\hline $\mathbf{P}$ & & $>0.9$ & $>0.2$ & $>0.8$ & $>0.6$ & $>0.2$ \\
\hline
\end{tabular}

*Twenty-eight patients had ampicillin, 11 nitrofurantoin, 3 gentamicin, 2 cephaloridine, 2 nalidixic acid, 1 sulphadimidine.

TABLE II-Data on Patients in both Treatment Groups who developed Leucopenia. Results expressed as Means \pm S.D.

\begin{tabular}{|c|c|c|c|c|c|c|c|c|}
\hline & $\begin{array}{c}\text { Incidence } \\
\text { of } \\
\text { Leucopenia }\end{array}$ & $\begin{array}{c}\text { Days after } \\
\text { Transplantation } \\
\text { at Start of } \\
\text { Treatment }\end{array}$ & $\begin{array}{c}\text { Onsei of } \\
\text { Leucopenia } \\
\text { after Start } \\
\text { of } \\
\text { Treatment } \\
\text { (Days) }\end{array}$ & $\begin{array}{c}\text { Duration } \\
\text { of } \\
\text { Leucopenia } \\
\text { (Days) }\end{array}$ & $\begin{array}{c}\text { Blood } \\
\text { Urea } \\
(\mathrm{mg} / 100 \mathrm{ml})\end{array}$ & $\begin{array}{c}\text { Azathioprine } \\
\text { (mg/day) }\end{array}$ & $\begin{array}{l}\text { Prednisone } \\
\text { (mg/day) }\end{array}$ & $\begin{array}{c}\text { W.B.C. at } \\
\text { Start of } \\
\text { Treatment } \\
/ \mathrm{mm}^{3}\end{array}$ \\
\hline $\begin{array}{l}\text { Co-trimoxazole } \\
\text { Other antibiotics }\end{array}$ & $\begin{array}{r}5 / 47(10.6 \%) \\
11 / 47(23.6 \%)\end{array}$ & $\begin{array}{l}79 \cdot 0 \pm 94 \cdot 4 \\
44 \cdot 9 \pm 27 \cdot 7\end{array}$ & $\begin{array}{l}12.4 \pm 4.8 \\
13.8 \pm 7.5\end{array}$ & $\begin{array}{l}12.6 \pm 9.0 \\
12.7 \pm 7.7\end{array}$ & $\begin{array}{l}123.0 \pm 65.9 \\
148.2 \pm 87.5\end{array}$ & $\begin{array}{l}80 \cdot 2 \pm 44 \cdot 3 \\
84 \cdot 1 \pm 28 \cdot 0\end{array}$ & $\begin{array}{l}71 \cdot 0 \pm 75 \cdot 5 \\
80.0 \pm 63.3\end{array}$ & $\begin{array}{l}7,400 \cdot 0 \pm 2,073 \cdot 6 \\
7,454 \cdot 5 \pm 2,252 \cdot 2\end{array}$ \\
\hline $\mathbf{P}$ & $>0.1$ & $>0.4$ & $>0.6$ & $>0.9$ & $>0.5$ & $>0.8$ & $>0.8$ & $>0.9$ \\
\hline
\end{tabular}

TABLE III-Comparison of Patients who developed Leucopenia with those who did not. Results expressed as Means \pm S.D.

\begin{tabular}{|c|c|c|c|c|c|c|}
\hline & $\begin{array}{l}\text { No. of } \\
\text { Patients }\end{array}$ & $\begin{array}{l}\text { Days after } \\
\text { Transplantation at } \\
\text { Start of Treatment }\end{array}$ & $\begin{array}{l}\text { Blood Urea } \\
(\mathrm{mg} / 100 \mathrm{ml})\end{array}$ & $\begin{array}{l}\text { Azathioprine } \\
\text { (mg/day) }\end{array}$ & $\begin{array}{l}\text { Prednisone } \\
\text { (mg/day) }\end{array}$ & $\begin{array}{l}\text { W.B.C. at Start of } \\
\text { Treatment } / \mathrm{mm}^{2}\end{array}$ \\
\hline $\begin{array}{l}\text { Leucopenic patients } \\
\text { Non-leucopenic patients }\end{array}$ & $\begin{array}{l}16 \\
78\end{array}$ & $\begin{array}{c}55 \cdot 6 \pm 56 \cdot 2 \\
239 \cdot 0 \pm 254 \cdot 0\end{array}$ & $\begin{array}{r}140 \cdot 3 \pm 80 \cdot 1 \\
74 \cdot 4 \pm 54 \cdot 2\end{array}$ & $\begin{array}{l}82 \cdot 6 \pm 32 \cdot 4 \\
92 \cdot 7 \pm 28 \cdot 2\end{array}$ & $\begin{array}{l}77.2 \pm 64.9 \\
31.5 \pm 30.5\end{array}$ & $\begin{array}{l}7,437 \cdot 5 \pm 2,128 \cdot 1 \\
8,884 \cdot 6 \pm 3,471 \cdot 5\end{array}$ \\
\hline $\mathbf{P}$ & & $<0.01$ & $<0.01$ & $>0.2$ & $<0.001$ & $>0.1$ \\
\hline
\end{tabular}

leucopenia between the group treated with co-trimoxazole and that treated with other antibiotics. The critical factor was the dosage of azathioprine in relation to the function of the renal transplant. Azathioprine is known to be partly excreted by the kidney (Elion et al., 1972), and the patients who developed a leucopenia had significantly poorer transplant function than those that did not, yet they received a similar dosage of azathioprine.

Further evidence for the argument that it is the azathioprine and neither the co-trimaxazole nor the other antibiotics used that produce the leucopenia is provided by the three patients in the restrospective survey and the five in this trial who developed a leucopenia while receiving co-trimoxazole. In all eight patients the azathioprine was withdrawn while the co-trimoxazole was continued throughout the leucopenia and the recovery from it.
Thus, we have no evidence with which to incriminate the combination of co-trimoxazole and azathioprine as a more potent cause of leucopenia than azathioprine alone.

I thank Mr. A. D. Barnes, Mr. P. Dawson-Edwards, Dr. B. Robinson, and Dr. J. D. Blainey for their help in the preparation of this paper.

\section{References}

Bateman, G. (1973). Lancot, 2, 1153.

Brumfitt, W., and Pursell, R. (1972). British Medical fournal, 2, 673.

Elion, G. B., et al. (1962). Cancer Chemotherapy Reports, No. 16, 197.

Evan, D. I. K., and Tell, R. (1969). British Medical fournal, 1, 578.

Grüneberg, R. N., and Kolbe, R. (1969). British Medical fournal, 1, 545.

Hulme, B., and Reeves, D. S. (1971). British Medical fournal, 3, 610 .

McCarthy, O. R. (1969). British Medical fournal, 3, 113.

Paulley, W. (1970). British Medical fournal, 2, 364

Reeves, D. S., et al. (1969). British Medical fournal, 1, 541. Department of Gastroenterology, Sahlgren's Hospital, University

G. DOTEVALL, M.D., Associate Professor of Gastroenterology

E. GROLL, M.D., Research Associate, (Present address: Sturegatan, 8, Stockholm, Sweden) tion to exclude organic disease the patients were followed up over two treatment periods of four weeks each under either placebo or the active principle, each patient being his own control. The results indicated that the drug had a beneficial effect $(P<0.05)$ provided that it was given for a period of at least three weeks.

\section{Introduction}

The irritable bowel syndrome is one of the most common disorders of the gastrointestinal tract (Kirsner and Palmer, 1958). It presents with a variety of symptoms and usually 